\title{
CHANGES IN STRUCTURE OF NON-ONCOLOGICAL MORBIDITY AND MORTALITY OF INHABITANTS OF RADIACTIVELY POLLUTED AREAS: EPIDEMIOLOGIC SURVEILLANCE 1988-2015
}

Prykashchykova K.Ye., Pavlovskyi Ye.Ye., Kostiuk G.V., Kapustinska O.A., Yaroshenko Zh.S. , Lukianiuk V.A., Olepir O.V., Sirovenko V.I., Romanenko N.T.

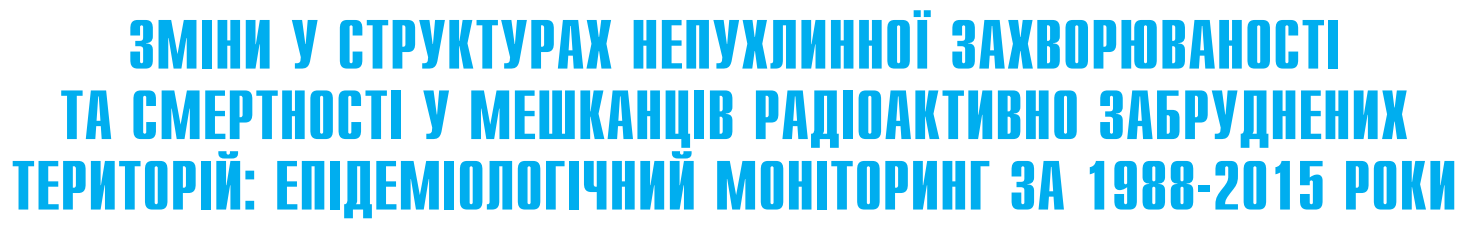

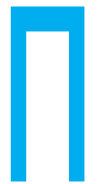

ПРИКАЩИКОВА К.Є., ПАВЛОВСЬКИЙ Є.Є., КОСТЮК Г.В., КАПУСТИНСЬКА О.А., ЯРОШЕНКО Ж.С., ЛУК'ЯНЮК В.О., ОЛЕПІР О.В., СИРОВЕНКО В.І., РОМАНЕНКО Н.Т. Національний науковий центр радіаційної медицини НАМН України, м. Київ

УДК 616-036.22.88:614.876:314.44

Ключові слова: аварія на Чорнобильській AEC, жителі радіоактивно забруднених територій, структура непухлинної захворюваності, структура причин смертності, залежність від статі і віку, хвороби системи кровообігу, хвороби ендокринної системи.

ИЗМЕНЕНИЯ В СТРУКТУРАХ НЕОПУХОЛЕВОЙ ЗАБОЛЕВАЕМОСТИ И СМЕРТНОСТИ У ЖИТЕЛЕЙ РАДИОАКТИВНО ЗАГРЯЗНЕННЫХ ТЕРРИТОРИЙ: ЭПИДЕМИОЛОГИЧЕСКИЙ МОНИТОРИНГ

ЗА 1988-2015 ГОДЫ

Прикащикова Е.Е., Павловский Е.Е., Костюк Г.В., Капустинская О.А., Ярошенко Ж.С., Лукьянюк В.А., Олепир О.В., Сировенко В.И., Романенко Н.Т. Национальный научний центр радиационной медицины НАМН Украины, г. Киев

Цель исследования: установление особенностей изменений структур неопухолевой заболеваемости и причин смертности с учетом пола и возраста на момент аварии на ЧАЭС жителей радиоактивно загрязненных территорий за 1988-2015 годы эпидемиологического наблюдения.

Материалы и методы. Для эпидемиологического исследования неопухолевой заболеваемости и смертности жителей РЗТ в послеаварийном периоде за 1988-2015 годы сформирована когорта лиц из населенных пунктов Житомирской, Киевской, Черниговской, Ровенской областей, соответственно Овручского, Иванковского, Козелецкого, Рокитновского районов по данным Государственного реестра Украины (ГРУ). В когорту включено 98902 лица с учетом возраста на момент аварии на ЧАЭС, пола, суммарных индивидуальных доз в пределах от менее 13... 40 мГр и более, накопленных за послеаварийный период хронического радиационного облучения с 1986 года. Дозы реконструированы в ННЦРМ и переданы в ГРУ. Жители РЗТ в общей когорте в возрасте до 60 лет на момент аварии на ЧАЭС распределены по принадлежности к полу и возрасту. Результаты. Проведено когортное эпидемиологическое исследование развития неопухолевой заболеваемости жителей РЗТ в возрасте до 60 лет на ісля техногенної аварії на Чорнобильській атомній електростанції (ЧАЕС) наукові дослідження свідчать про негативні медичні зміни у стані здоров'я мешканців радіоактивно забруднених територій (РЗТ). Особливість полягає у тому, що потерпілі перебувають під постійним хронічним радіаційним опроміненням від довготривалих радіонуклідів $\left({ }^{137} \mathrm{Cs}\right.$, $\left.{ }^{134} \mathrm{Cs}, 90 \mathrm{Sr}\right)$. Спостерігається погіршення стану здоров'я мешканців РЗТ, яке пов'язане переважно зі збільшенням рівня непухлинної захворюваності та смертності [1-4]. Згідно з нормами величина накопиченої дози за рік не повинна перевищувати 1 мГр. Окремі публікації свідчать про вплив не тільки максимальних, а й малих доз радіації (до 1 Гр) на розвиток непухлинних захворювань й про залежність від таких немодифікованих чинників, як стать і вік особи на момент аварії на ЧАЕС [5-9].

Отже, для мешканців РЗТ України особливо важливим $є$ постійне проведення досліджень розвитку непухлинної захворюваності та причин смертності залежно від таких немодифікованих нерадіаційних

момент аварии на ЧАЭС на протяжении 1988-2015 годов. В результате анализа выявлено, что общая заболеваемость жителей РЗТ в зависимости от возраста на момент аварии находится почти в одинаковых параметрах показателя и отличается в процентном соотношении мало: у лиц менее 18 лет 34\%, у 18-39-летних - 36\%, у 40-60-летних - 30\%. В течение мониторинга отмечалась значительная смертность (77\%) лиц 40-60 лет по сравнению с меньшими возрастными категориями (20\% лиц 1839 лет и $3 \%$ лиц до 18 лет). Рост доли смертности жителей с увеличением их возраста обусловлена значительной долей болезней системы кровообращения в структуре неопухолевой заболеваемости независимо от пола и возраста на момент аварии на ЧАЭС. В младшей возрастной категории жителей болезни системы кровообращения составили 5,44\%, у 18-39-летних - уже на 8, 13\% больше, у 4060-летних - на 25,27\% больше на фоне уменьшения долей других болезней в структуре неопухолевой заболеваемости. Также можно отметить уменьшение болезней эндокринной системы, которые занимали значительное место в структуре заболеваемости у жителей самой младшей возрастной категории (20\% - улиц до 18 лет, до 2,91\% - у 18 39-летних, до 1,99\% - у 40-60-летних жителей). Заключение. Учитывая, что у жителей РЗТ в течение периода исследования в основном развитие неопухолевых болезней и причины смертности были значительными по болезням системы кровообращения, в дальнейшем важно проанализировать структуры нозологических форм данного класса.

Ключевые слова: авария на Чернобыльской АЭС, жители PЗТ, структура неопухолевой заболеваемости, структура причин смертности, зависимость от пола и возраста, болезни системы кровообращения, болезни эндокринной системы.

๑ Прикащикова К.Є., Павловський Є.Є., Костюк Г.В., Капустинська О.А., Ярошенко Ж.С., Лук'янюк В.О., Олепір О.В., Сировенко В.І., Романенко Н.Т. СТАТТЯ, 2017. 
факторів, як стать і вік особи на момент катастрофи на ЧАЕС.

Мета дослідження: встановлення особливостей змін структур непухлинної захворюваності та причин смертності з урахуванням статі та віку на момент аварії на ЧАЕС мешканців радіоактивно забруднених територій за 1988-2015 роки епідеміологічного спостереження.

Матеріали і методи. Для епідеміологічного дослідження непухлинної захворюваності та смертності мешканців РЗТ у післяаварійному періоді за 1988-2015 роки сформовано когорту осіб із населених пунктів Житомирської, Київської, Чернігівської, Рівненської областей, відповідно Овруцького, Іванківського, Козелецького, Рокитнівського районів за даними Державного реєстру України (ДРУ). До когорти увійшли 98902 особи 3 урахуванням їхнього віку на момент аварії на ЧAЕC, статі, сумарних індивідуальних доз у межах від 13...40 мГр і більше, накопичених за післяаварійний період хронічного радіаційного опромінення з 1986 року. Дози реконструйовано у ННЦРМ професором І.А. Ліхтарьовим зі співробітниками і передано до Державного реєстру України [10]. Мешканці РЗТ у загальній когорті віком до 60 років на момент аварії на ЧАЕС розподілені за приналежністю до статі та віку (табл. 1).

Для епідеміологічного дослідження розвитку непухлинної захворюваності та смертності були обрані хвороби основних класів за MKX-10, а саме: органів травлення, дихання, хвороб кровообігу, ендокринної, сечостатевої, нервової та кістково-м'язової систем.

Для епідеміологічного дослідження структури (C) непухлинної захворюваності та причин смертності потерпілих за 1988-2015 роки спостережен-

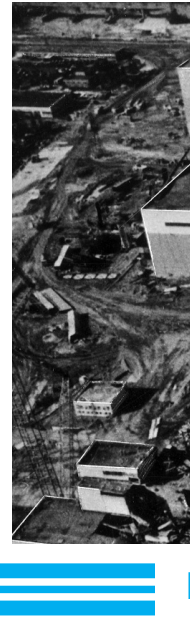

ня розраховувалися відсотки тих чи інших хвороб від загальної чисельності хвороб за формулою:

$$
C=a \cdot 100 / A, \%
$$

де а - пошукове значення нозологічної форми; $A$ - сума усіх випадків нозологічних форм [11].

Результати. У результаті когортного епідеміологічного дослідження розвитку непухлинної захворюваності мешканців РЗТ віком до 60 років на момент аварії на ЧАЕС протягом 1988-2015 років виявлено 111713 випадків непухлинної захворюваності. Внесок вікових категорій у розвиток непухлинної захворюваності осіб до 18 років, 18-39 років, 40-60 років майже однаковий (рис. 1). За статтю внесок у структуру непухлинної захворюваності у жінок становить $64,67 \%$, у чоловіків - 35,33\%. Водночас за цей період спостереження зареєстровано 11388 випадків смертності, з яких найбільший відсоток припав на мешканців РЗТ віком 40-60 років на момент аварії на ЧАЕС. Порівняно з ними значно менше на $57 \%$ померлих віком 18-39 років, менше на $74 \%$ - до 18 років на момент аварії на ЧАЕС.

Отже, внесок вікових категорій у розвиток непухлинної захворюваності майже однаковий, але жінки хворіють частіше. 3 віком смертність зростає стрімко, особливо у найстаршій віковій категорії. За стате-

Таблиця 1

Розподіл суб'єктів вікових когорт відповідно до середніх індивідуальних сумарних доз, накопичених за роки хронічного радіаційного опромінення від 26.04.1986 р.

\begin{tabular}{|c|c|c|c|}
\hline $\begin{array}{c}\text { Вік на } \\
\text { момент } \\
\text { аварії на } \\
\text { ЧАЕС, роки }\end{array}$ & $\begin{array}{c}\text { Чисельність } \\
\text { мешканців РЗТ, }\end{array}$ & $\begin{array}{c}\text { Спів- } \\
\text { відношення } \\
\text { аболютне число } \\
\text { за віком, \% }\end{array}$ & $\begin{array}{c}\text { Середня } \\
\text { індивідуальна сумарна } \\
\text { доза, накопичена 3 } \\
1986 \text { року, мГр }\end{array}$ \\
\hline До18 & 33713 & 34,08 & $14,31 \pm 8,69$ \\
\hline $18-39$ & 34818 & 35,20 & $19,06 \pm 12,20$ \\
\hline $40-60$ & 30371 & 30,72 & $18,48 \pm 13,36$ \\
\hline $0-60$ & 98902 & 100 & $16,86 \pm 11,61$ \\
\hline
\end{tabular}

вою приналежністю внесок у структуру причин смертності майже однаковий.

у структурі непухлинної захворюваності найбільші частки виявлені відповідно до рангу за хворобами органів дихання, травлення, системи кровообігу, які разом становлять $68 \%$ (рис. 2). Ще значними за величиною у структурі непухлинної захворюваності потерпілих залишаються хвороби ендокринної, нервової, сечостатевої, кістково-м'язової систем. Найменші частки за розладами поведінки та психіки. Основними причинами смерті протягом даного моніторингу стали хвороби органів дихання і органів травлення, системи кровообігу, які разом становлять 92\%. Отже, основними причинами розвитку непухлинної захворюваності та причинами смерті були однакові нозологічні форми. Натомість провідне місце у структурі причин смертності належить хворобам системи кровообігу, що склали 66\%.

Структура непухлинної захворюваності у мешканців РЗТ Внесок вікової категорії 2015 роки у структуру

\section{а - непухлинної захворюваності}

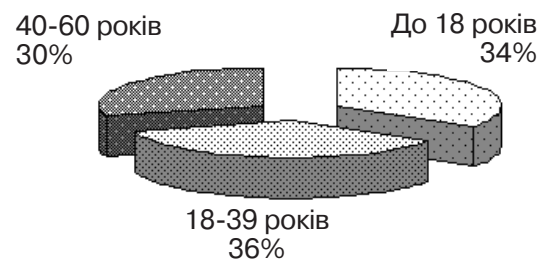

б - причин смертності

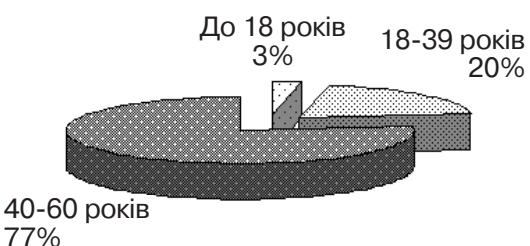

$77 \%$ 
залежно від віку на момент аварії на ЧАЕС за 1988-2015 роки характеризується тим, що 3 віком змінюється пріоритетність хвороб у структурі непухлинної захворюваності, а саме: відбувається перерозподіл хвороб за віком у мешканців Р3Т (табл. 2). Так, у віковій категорії до 18 років та 18-39 років перше місце посідають хвороби органів дихання, у 4060-річних - хвороби системи кровообігу.

Друге місце в осіб до 18 років поділяють хвороби сечостатевої та ендокринної систем, бо мають майже однакові проценти, у 18-39-річних на другому місці - хвороби сечостатевої системи, у 40-60-річних - хвороби органів дихання та сечостатевої системи. Третє місце $(4,05-13,57 \%)$ в осіб до 18 років встановлено за хворобами нервової системи, системи кровообігу, органами травлення, хворобами кістково-м'язової системи; в осіб 18-39 років - за хворобами системи кровообігу, органів травлення, нервової системи, кістково-м'язової системи; у 40-60-річних - за хворобами кістково-м'язової та нервової систем, органів травлення. Розлади психіки та поведінки майже не відрізняються у вікових категоріях.

Отже, у старших мешканців РЗТ порівняно з наймолодшою віковою категорією до 18 років спостерігається різке зменшення відсотків хвороб ендокринної системи, а саме: у 1839-річних осіб - на $17,85 \%$, у 40-60-річних - на. $18,77 \%$. На- томість у 18-39-річних порівняно з молодшими наявність Хвороб системи кровообігу збільшується на $8,13 \%$, органів травлення - на $7,19 \%$, хвороб нервової системи - на 2,82\%, хвороб кістково-м'язової системи - на 1,78\%; у 40-60-річних відповідно - на 24,27\%, 1,95\%, $1,17 \%, 7,04 \%$. Хвороби сечостатевої системи в усіх мешканців, незалежно від віку, залишаються 3 однаковими відсотками

Таким чином, зміни у структурі непухлинної захворюваності відбулися за рахунок зменшення хвороб ендокринної системи у мешканців 18-39 років та 40-60 років порівняно з особами до 18 років. Але паралельно спостерігалося значне збільшння хвороб системи кровообігу в обох старших вікових категоріях, а також хвороб органів травлення у 1839-річних, хвороб кістково-

м'язової системи - у 40-60-річних. Отже, у мешканців до 18 років спостерігається найбільший процент хвороб органів дихання, сечостатевої та ендокринної систем, в осіб 18-39 років - органів дихання, сечостатевої системи, системи кровообігу та органів травлення, в осіб 40-60 років - хвороб системи кровообігу та хвороб кістково-м'язової системи.

Незалежно від статі чинними складовими у структурі непухлинної захворюваності мешканців є хвороби органів дихання, травлення, системи кровообігу (табл. 3). У чоловіків і жінок значні відсотки ще значаться за хворобами ендокринної, нервової, кістково-м'язової систем. У жінок порівняно 3 чоловіками перевищують хвороби сечостатевої системи. Найменші частки у структурі у чоловіків і жінок - за розладами

Таблиця 2

\section{Структура непухлинної захворюваності мешканців РЗТ залежно від віку на момент аварії на ЧАЕС} за 1988-2015 роки, \%

\begin{tabular}{|c|c|c|c|}
\hline \multirow[t]{2}{*}{ Клас хвороб за МКХ10 } & \multicolumn{3}{|c|}{$\begin{array}{c}\text { Вік мешканців РЗТ на } \\
\text { момент аварії на ЧАЕС, } \\
\text { роки }\end{array}$} \\
\hline & До 18 & $18-39$ & $40-60$ \\
\hline Хвороби ендокринної системи (Е00-Е90) & 20,76 & 2,91 & 1,99 \\
\hline Розлади психіки та поведінки (F00-F99) & 1,76 & 2,08 & 1,80 \\
\hline Хвороби нервової системи (G00-G99) & 5,50 & 8,32 & 6,67 \\
\hline Хвороби системи кровообігу (I00-199) & 5,44 & 13,57 & 30,71 \\
\hline Хвороби органів дихання (J00-J99) & 36,68 & 35,58 & 21,70 \\
\hline Хвороби органів травлення (К00-К93) & 4,27 & 11,46 & 6,22 \\
\hline Хвороби сечостатевої системи (N00-N99) & 21,54 & 20,23 & 19,78 \\
\hline Хвороби кістково-м'язової системи (М00-М 99) & 4,05 & 5,83 & 11,09 \\
\hline
\end{tabular}

Рисунок 2

\section{Структури непухлинної захворюваності та причин смертості мешканців РЗТ віком} до 60 років на момент аварії на ЧАЕС за основними класами хвороб

\section{Структура непухлинної захворюваності}

\section{Структура причин смертності}

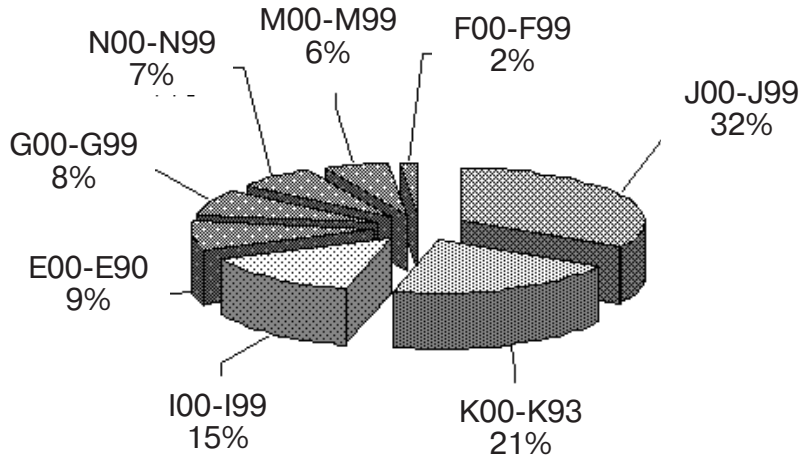

Примітки: ЕОО-Е90 - хвороби ендокринної системи, розладу харчування та порушення обміну;

FOO-F99 - розлади психіки та поведінки;

G00-G99 - хвороби нервової системи;

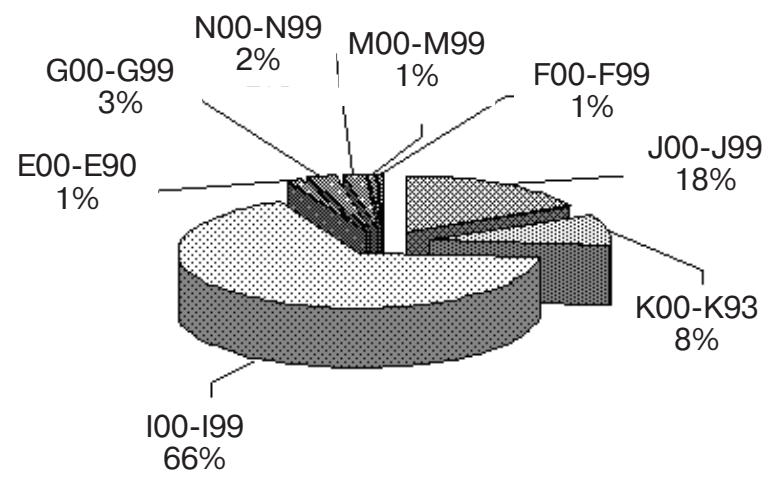

100-199 - хвороби системи кровообігу; J00-J99 - хвороби органів дихання; К00-К9З - хвороби органів травлення; NOO-N99 - хвороби сечостатевої системи; М00-М99 - хвороби кістково-м'язової системи. 
CHANGES IN THE STRUCTURE OF NON-ONCOLOGICAL MORBIDITY AND MORTALITY OF INHABITANTS OF RADIACTIVELY POLLUTED AREAS:

EPIDEMIOLOGIC MONITORING IN 1988-2015

Prykashchykova K. Ye., Pavlovskyi Ye.Ye.

Kostiuk G.V., Kapustinska O.A., Yaroshenko Zh.S., Lukianiuk V.A., Olepir O.V., Sirovenko V.I., Romanenko N.T.

National Research Center for Radiation Medicine of NAMS of Ukraine, Kyiv

Objective. We established the features of the changes in the structures of non-tumorous morbidity and mortality causes in the residents of radioactively contaminated territories (RCT) taking into account their gender and age at the moment of the accident at the Chornobyl NPP in the period of epidemiologic monitoring in 1988-2015.

Materials and methods. For epidemiological evaluation of non-tumorous morbidity and mortality among the residents of radioactively contaminated territories in the post-accident period of 1988-2015 we created a cohort of the individuals from the settlements of Zhytomyr Kyiv, Chernihiv, and Rivne oblasts, accordingly, from Ovruch, Ivankiv, Kozelets, Rokitneiv regions by the data of the State Register of Ukraine (SRU). 98902 persons were included in the cohort taking into account their age at the moment of the Chornobyl accident, gender, total individual doses in the limits less than 13 and over $40 \mathrm{mGr}$ accumulated during the post-accident period of chronic radiation exposure since 1986. The doses were reconstructed in the NNCRM and passed to the SRU. In the total cohort at the age under 60 at the moment of the Chornobyl accident the residents of the RCT were divided by their gender and age.

Results. We performed the cohort epidemiologic study of non-tumorous morbidity and mortality of the residents of the RCT at the age under 60 at the moment of the accidents at the Chornobyl NPP during 1988-2015. As a result of analysis it was revealed that general morbidity by age in the residents of the RCT was practically identical and was little different in percentage in the individuals aged under 18 years old $34 \%, 18-39$ years old $-36 \%$, 40-60 years old $-30 \%$. During the monitoring, a high mortality $(77 \%)$ in the individuals aged $40-60$ years old in comparison with younger age categories (20\% of the persons aged 18 39 years old and 3\% of the persons aged under 18 years old) was observed. Increase of the mortality in the residents with an increase of their age was stipulated by a significant part of the diseases of circulatory system in the structure of non-tumorous mortality irrespective of their gender and age at the moment of accident at the Chornobyl NPP. We can also point out a decrease of the diseases of endocrine system that occupies a significant place in the morbidity structure in the residents of the youngest age category $(20 \%$ of the persons aged under 18 years old, up to $2.91 \%$ of the residents aged 18-39 years old, and up to $1.99 \%$ of the residents aged 40-60 years old).

Conclusions. Taking into account that mainly the development of non-tumorous diseases and mortality causes of circulatory system diseases were significant in the residents of the RCT during the period of the study, further it should be important to analyze a structure of nosological forms of this class.

Keywords: accident at the Chornobyl NPP, residents of radioactively contaminated territories, structure of non-tumorous morbidity, structure of mortality causes, dependence on gender and age, circulatory system diseases, endocrine diseases. психіки та поведінки

У структурі причин смертності за 1988-2015 роки у жінок і чоловіків провідними складовими є хвороби системи кровообігу (табл. 4). Решта хвороб у жінок становить $32,54 \%$, у чоловіків - 34,21\%, з яких значними частками вирізняються хвороби органів дихання та травлення. 3 таблиці 4 видно, що жінки вдвічі частіше вмирають через хвороби ендокринної та сечостатевої систем, чоловіки - через розлади психіки та поведінки. Проте частки причин смерті через інші непухлинні хвороби майже однакові у жінок і чоловіків.

Структуру причин смертності мешканців РЗТ залежно від віку на момент аварії на ЧАЕС за 1988-2015 роки подано у таблиці 5. На першому місці у структурі причин смертності хвороби системи кровообігу, на другому - хвороби сечостатевої системи в осіб до 18 років і 18-39 років, хвороби органів дихання - у 40-60-річних. Третє місце посідають хвороби органів дихання і нервової системи в осіб до 18 років, хвороби сечостатевої системи - в осіб 18-39 років, хвороби органів дихання - в осіб 40-60 років. Треба зазначити, що з віком знижуються відсотки причин смертності усіх хвороб, крім хвороб системи кровообігу

Отже, особливість структури причин смертності через непухлинні хвороби полягає у тому, що відсотки причин смертності усіх хвороб зменшуються зі збільшенням віку мешканців РЗТ, крім хвороб системи кровообігу. Хвороби системи кровообігу серед причин смертності найчастіші в усіх вікових категоріях, а 3 віком зростає складова цих нозологічних форм майже на 20\%. Особи віком до 18 та 18-

39 років ще мають високу смертність через хвороби сечостатевої системи, органів дихання та нервової системи. Натомість в осіб віком 40-60 років основною причиною смертності $€$ хвороби системи кровообігу.

Таким чином, з аналізу структури непухлинної захворюваності та смертності у мешканців РЗТ (92908 осіб) до 60 років на момент аварії на ЧАЕС за 19882015 роки встановлено таке. Внески у загальну захворюваність мешканців РЗТ залежно від віку на момент аварії на ЧАЕС перебувають майже в однакових параметрах показ-

Таблиця 3

Структура непухлинної захворюваності мешканців РЗТ віком до 60 років на момент аварії на ЧАЕС залежно від статі за 1988-2015 роки, \%

\begin{tabular}{|l|c|c|}
\hline \multicolumn{1}{|c|}{ Клас хвороб за МКХ10 } & Чоловіки & Жінки \\
\hline Хвороби ендокринної системи (Е00-E90) & 9,81 & 8,12 \\
\hline Розлади психіки та поведінки (F00-F99) & 2,31 & 1,13 \\
\hline Хвороби нервової системи (G00-G99) & 6,91 & 8,68 \\
\hline Хвороби системи кровообігу (I00-I99) & 15,02 & 15,71 \\
\hline Хвороби органів дихання (J00-J99) & 36,94 & 31,41 \\
\hline Хвороби органів травлення (К00-К93) & 21,76 & 19,94 \\
\hline Хвороби сечостатевої системи (N00-N99) & 3,16 & 9,61 \\
\hline Хвороби кістково-м'язової системи (М00-M99) & 6,32 & 5,37 \\
\hline
\end{tabular}


ника і відрізняються за відсотками мало: в осіб до 18 років 34\%, у 18-39-річних - 36\%, у 4060-річних - 30\%. За час моніторингу відзначено 77\% смертності в осіб 40-60 років порівняно з молодшими віковими категоріями (20\% в осіб 18-39 років та 3\% - до 18 років). Зростання частки смертності мешканців 3 віком зумовлена значною часткою хвороб системи кровообігу у структурі непухлинної захворюваності незалежно від статі та віку на момент аварії на ЧАЕС. Так, у наймолодших мешканців хвороби системи кровообігу становили 5,44\%, у 18-39річних - вже на 8,13\% більше, у 40-60-річних - на 25,27\% на фоні зменшення часток інших хвороб у структурі непухлинної захворюваності. Особливо прослідковується зменшення хвороб ендокринної системи, яким належала значна частка у структурі захворюваності (20\% - в осіб до 18 років, до 2,91\% - у 18-39-річних, до $1,99 \%$ - у 40 60-річних мешканців).

Висновки

1. У структурі непухлинної захворюваності мешканців РЗТ за 1988-2015 роки за результа-

Смертність через непухлинну захворюваність мешканців РЗТ віком до 60 років на момент аварії на ЧАЕС залежно від статі за $1988-2015$ роки, \%

\begin{tabular}{|l|c|c|}
\hline \multicolumn{1}{|c|}{ Клас хвороб за МКХ10 } & Чоловіки & Жінки \\
\hline Хвороби ендокринної системи (E00-E90) & 0,89 & 1,91 \\
\hline Розлади психіки та поведінки (F00-F99) & 0,74 & 0,36 \\
\hline Хвороби нервової системи (G00-G99) & 2,56 & 2,62 \\
\hline Хвороби системи кровообігу (I00-I99) & 65,79 & 67,46 \\
\hline Хвороби органів дихання (J00-J99) & 18,73 & 16,73 \\
\hline Хвороби органів травлення (К00-К93) & 9,63 & 7,31 \\
\hline Хвороби сечостатевої системи (N00-N99) & 1,02 & 2,91 \\
\hline Хвороби кістково-м'язової системи (М00-М99) & 0,62 & 0,70 \\
\hline
\end{tabular}

Смертність мешканців РЗТ залежно від віку на момент аварії на ЧАЕС за 1988-2015 роки, \%

\begin{tabular}{|c|c|c|c|}
\hline \multirow[t]{2}{*}{ Клас хвороб за МКХ10 } & \multicolumn{3}{|c|}{$\begin{array}{c}\text { Вік мешканців РЗТ на } \\
\text { момент аварії на ЧАЕС, } \\
\text { роки }\end{array}$} \\
\hline & До 18 & $18-39$ & $40-60$ \\
\hline Хвороби ендокринної системи (Е00-Е90) & 2,12 & 1,23 & 0,47 \\
\hline Розлади психіки та поведінки (F00-F99) & 3,64 & 1,79 & 0,05 \\
\hline Хвороби нервової системи (G00-G99) & 7,27 & 2,06 & 0,34 \\
\hline Хвороби системи кровообігу (I0-199) & 59,39 & 78,32 & 92,23 \\
\hline Хвороби органів дихання (J00-J99) & 7,88 & 6,17 & 5,16 \\
\hline Хвороби органів травлення (К00-К93) & 1,82 & 0,79 & 0,35 \\
\hline Хвороби сечостатевої системи (N00-N99) & 17,88 & 9,63 & 1,36 \\
\hline Хвороби кістково-м'язової системи (М00-М99) & 0 & 0 & 0,04 \\
\hline
\end{tabular}

60-річних осіб на фоні стрімкого збільшення хвороб системи кровообігу від 5,44\% до 13,57\% та 30,71\% відповідно.

4. Найбільший внесок у загальну смертність мешканців РЗТ відбувся у віковій категорії 40-60 років, найменший - у віці до 18 років на момент аварії на ЧAEC. Незалежно від віку та статі мешканців РЗТ основними причинами смертності серед непухлинних хвороб були переважно хвороби системи кровообігу, потім хвороби сечостатевої системи та органів дихання.

5. Зростання смертності мешканців РЗТ зі збільшенням їхнього віку зумовлене значною часткою хвороб системи кровообігу у структурі непухлинної захворюваності незалежно від статі та віку на момент аварії на ЧАЕС. Так, у наймолодших хвороби системи кровообігу становили 5,44\%, у 18-39-річних вже на 8,13\% більше, у 40-60річних - на 25,27\% більше на фоні зменшення часток інших хвороб у структурі непухлинної захворюваності, особливо хвороб ендокринної системи, які складали значну частку у структурі.

6. Враховуючи, що у мешканців РЗТ за досліджуваний період розвиток непухлинних хвороб та причин смертності був значним переважно за хворобами системи кровообігу, важливе у подальшому проведення аналізу структури за нозологічними формами цього класу.

ЛІТЕРАТУРА

1. Бузунов В.О. Актуальные проблемы эпидемиологии медицинских последствий в отдаленном периоде аварии на ЧАЭС. Эпидемиология медицинских последствий аварии на Чернобыльской АЭС. 20 лет спустя : тез. докл. междунар. науч. -практ. конф. Донецк : Вебер, 2007. 35 с.

2. Прикащикова К.Є., Бузунов В.О., Ярошенко Ж.І. та ін. Особливості структури непухлинної захворюваності в евакуйованих у дитячому і підлітковому віці на момент аварії на ЧАЕС, період дослідження 1993-2012 рр. Довкілля і здоров'я : матеріали науковопракт. конф. Тернопіль, 2015. C. $74-75$

3. Капустинська О.А., Прикащикова К.Є., Бузунов В.О., Ярошенко Ж.С. та ін. Динаміка рівня цереброваскулярних хвороб у дорослого населення, евакуйованого із зони від- 
чуження ЧАЕС, з дозами опромінення щитоподібної залози у діапазоні 0-2 Гр. Результати дескриптивного аналізу. Довкілля і здоров'я : матеріали наук. -практ. конф. Тернопіль, 2015. C. 23-24.

4. Камінський О.В. Особливості розвитку незлоякісної ендокринної патології у постраждалих внаслідок аварії на ЧАЕС та роль гормональних взаємозв'язків. Проблеми радіаційної медицини та радіобіології. Київ, 2014. Вип. 19. С. 256-266.

5. Бузунов В.А., Прикащикова К.Е., Костюк Г.В., Терещенко С.О., Губина И.Г. Эпидемиологический анализ развития сердечно-сосудистой заболеваемости у жителей радиационно загрязненных территорий вследствие катастрофы на ЧАЭС за 1988-2010 годы в зависимости от доз ионизирующего облучения, пола, возраста. Здоровье и окружающая среда : сб. науч. тр. Минск, 2013. Вып. 23

C. 189-193.

6. Шестопалов В.М., Набока М.В., Лихошерстов А.А., Чабан Е.П. Анализ дозозави симых эффектов при хроническом внутреннем облучении на примере заболеваемости болезнями желудочно-кишечного тракта у детского населения радиоактивно загрязненных районов Житомирской области. Радіобіологічні та радіоекологічні аспекти Чорнобильської катастрофи : матер.

конф. Славутич, 2011. С. 57.

7. Стефанович Г.В., Будерацька Н.О., Мехеда Л.В. Морфофункціональна характеристика ооцитів та доімплантаційних ембріонів жінок, що проживають на забруднених радіонуклідами територіях. $\mathrm{Pa}$ діобіологічні та радіоекологічні аспекти Чорнобильської катастрофи : зб. матер. міжнарод. конф. Славутич, 2011. С. 50.

8. Присяжнюк А.Є., Романенко А.Ю. Епідеміологічні дослідження стану здоров'я населення, яке мешкає на радіоактивно забруднених територіях. 25 років Чорнобильської катастрофи. Безпека майбутнього : національна доповідь України. Київ : KIM, 2011. C. 152-164.

9. Півень Н.В., Гунько Н.В., Короткова Н.В. Захворюваність дитячого населення найбільш радіоактивно забруднених територій України хворобами органів травлення.
Довкілля та здоров'я. 2014. № 4 (71). С. 55-60.

10. Лихтарев И.А., Фесенко Г.В., Масюк С.В., Замостян С.В. и др. Реконструкция индивидуальных доз облучения субъектов ГРУ : метод. рек. Киев : Укрмедпатентинформ, 2013. 24 с.

11. Бузунов В.О., Пирогова О.Я., Краснікова Л.І., Цупріков В.А., Войчулене Ю.С., Домашевська Т.Є. Показники та методи їх розрахунку в епідеміології неінфекційних захворювань : навч. посібник. Київ : Авіценна, 2013. 120 р.

REFERENCES

1. Buzunov V.O. Aktualnye problem epidemiologii meditsinskikh posledstviy $v$ otdalennom periode avarii na ChAES [Actual Problems of Epidemiology of Medical Consequences in the Remote Period of the Accident at the ChNPP]. In : Epidemiologiya meditsinskikh posledstviy avarii na ChAES [Epidemiology of Medical Consequences of the Accident at the Chornobyl NPP. 20 Years Later: Theses of the Report of the Intern. Sci.-Pract. Conf.]. Donezk : Veber ; 2007 : 35 p. (in Russian).

2. Prykashchykova K.Ye., Buzunov V.O., Yaroshenko Zh.S. et al. Osoblyvosti struktury nepukhlynnoi zakhvoriuvanosti v evakuiovanykh $v$ dytiachomu i pidlitkovomu vitsi na moment avarii na ChAES, period doslidzhennia 1993-2012. [Features of Non-Tumorous Morbidity Structure in the Evacuated at the Children's and the Adolescent's Ages at the Moment of the Accident at the ChNPP, 1993-2012 Study Period]. In : Dovkillia I zdorovia : materialy naukovo-prakt. konf. [Environment and Health : Materials of the Scientific-and-Practical Conf.]. Ternopil (Ukraine) ; 2015 : 74-75 (in Ukrainian).

3. Kapustynska O.A., Prykashchykova K.Ye., Buzunov V.O., Yaroshenko Zh.S. et al. Dynamika rivnia tserebrovaskuliarnykh khvorob u dorosloho naselennia, evakuiovanoho iz zony vidchuzhennia ChAES z dozamy oprominennia shchytopodibnoi zalozy u diapazoni 0-2 Gy [Dynamics of the Level of Cerebrovascular Diseases in the Adult Population, Evacuated from the Alienation Zone, with the Thyroid Gland Irradiation Doses in the Range of 0-2 Gr. Results of the Descriptive Analysis]. In : Dovkillia I zdorovia : materialy naukovo-prakt. konf. [Environment and Health : Materials of the Scientific-and-Practical Conf.]. Ternopil (Ukraine) ; 2015 : 23-24 (in Ukrainian).

4. Kaminskyi O. V. Osoblyvosti rozvytku nezloizkisnoi endokrynnoi patolohii u postrazhdalykh vnaslidok avarii yf ChAES ta rol hormonalnykh vzaemozviazkiv [Features of the Development of Non-Malignant Endocrine Pathology in the Suffered as a Result of the Accident at the ChNPP and Role of Hormonal Correlations]. In : Problemy radiatsiinoi medytsyny ta radiobiolohii: zb. nauk. pr. [Problems of Radiation Medicine and Radiobiology: Coll. Sci. Works]. Kyiv ; 2014; 19 : 256-266

(in Ukrainian).

5. Buzunov V.A., Prykashchykova K.E., Kostiuk G.V., Tereshchenko S.O. and Gubina I.G. Epidemiologicheskiy analiz razvitiya serdechno-sosudistoy zabolevayemosti u zhiteley radiazionno zagriaznennykh territoriy vsledstviye katastrofy na ChAES za 1988-2010 gody v zavisimosti ot doz ioniziruiushchego oblucheniya pola, vozrasta [Epidemiological Analysis of the Development of Cardiovascular Morbidity in the Residents, Living on the Radioactive Contaminated Territories, as a Result of the Catastrophe at the ChNPP for 1988-2012 Depending on the Ionizing Radiation Doses, Gender, Age]. In : Zdorovie I okruzhayushchaya sreda : sbornik nauchnykh trudov [Health and Environment: Coll. Sci. Works]. Minsk ; 2013 ; 23 : 189-193 (in Russian).

6. Shestopalov V.M., Naboka M.V., Likhosherstov A.A. and Chaban E.P. Analiz dozozavisimykh effektov pri khronicheskom vnutrennem obluchenii na primere zabolevaemosti bolezniami zheludochnokishechnogo trakta u detskogo naseleniya radioaktivno zagryaznennykh rayonov Zhytomirskoy oblasti [Analysis of DoseDepending Effects under Chronic Inner Irradiation in the Example of Gastrointestinal Diseases Morbidity in the Children's Population of the Radioactive Contaminated Regions of Zhytomyr Oblast]. In : Radiolohichni ta radioekolohichni aspekty Chornobylskoi katastrofy : mater. konf.

[Radiobiological and Radioecological Aspects of the Chornobyl Catastrophe : Mater. 
Conf.]. Slavutych (Ukraine) ; 2011 : P. 57 (in Russian).

7. Stefanovych H.V., Buderatska N.O. and Mekheda L.V. Morfofunktsionalna kharakterystyka oozytiv ta doimplantatsiynykh embrioniv zhinok, shcho prozhyvaiut na zabrudnenykh radionuklidamy terytoriiakh [Morphofunctional

Characteristic of the Oocytes and Pre-Implantation Embryos in the Females, Residing on the Territories Contaminated with Radionuclides]. In :

Radiolohichni ta radioekolohichni aspekty Chornobylskoi katastrofy : mater. konf.

[Radiobiological and Radioecological Aspects of the Chornobyl Catastrophe : Coll. Mater. Intern. Conf.]. Slavutych (Ukraine) ; 2011: P. 50 (in Ukrainian).

8. Prysiazhniuk A.Ye. and Romanenko A.Yu.

Epidemiolohichni doslidzhennia stanu zdorovia naselennia, yake meshkaie na radioaktyvno zabrudnenykh terytoriiakh

[Epidemiological Studies of the Health State of the Population, Residing on the Radioactive Contaminated Territories]. In : 25 rokiv Chornobylskoi katastrofy. Bezpeka maibutnioho [25 Years of the Chornobyl Catastrophe. Safety of the Future : National Report of Ukraine]. Kyiv : KIM; 2011 : 152164 (in Ukrainian).

9. Piven N.V., Hunko N.V. and Korotkova N.V. Dovkillia ta zdorovia. 2014 ; № 4 (71) : 5560 (in Ukrainian).

10. Likhtarev I.A., Fesenko G.V., Masiuk S.V., Zamostian S.V. et al. Rekonstruktsiya individualnykh doz oblucheniya subiektov Gosudarstvennoho reiestra Ukrainy : metod. rekomendatsii [Reconstruction of the Individual Irradiation Doses of the Subjects of the National Register of Ukraine : Method.

Recommendations]. Kiev : Ukrmedpatentinform ; 2013 : 24 p. (in Russian).

11. Buzunov V.O., Pyrohova O.Ya., Krasnikova L.I., Tsuprikov V.A. Voichulene Yu.S. and

Domashevska T.Ye. Pokaznyky ta metody ikh rozrahunku v epidemiolohii infektsiynykh zakhvoriuvan: navch. Posibnyk [Indices and Methods for their Calculation in the Epidemiology of Noninfectious Diseases: Manual]. Kyiv : Avitsenna ; 2013 120 p. (in Ukrainian).

Надійшла до редакції 17.01.2017

\section{DIRECTIVE 98/83/EC AND RADIDACTIVITY CONTROL OF DRINKING WATER IN UKRAINE Buzynnyi M.G.}
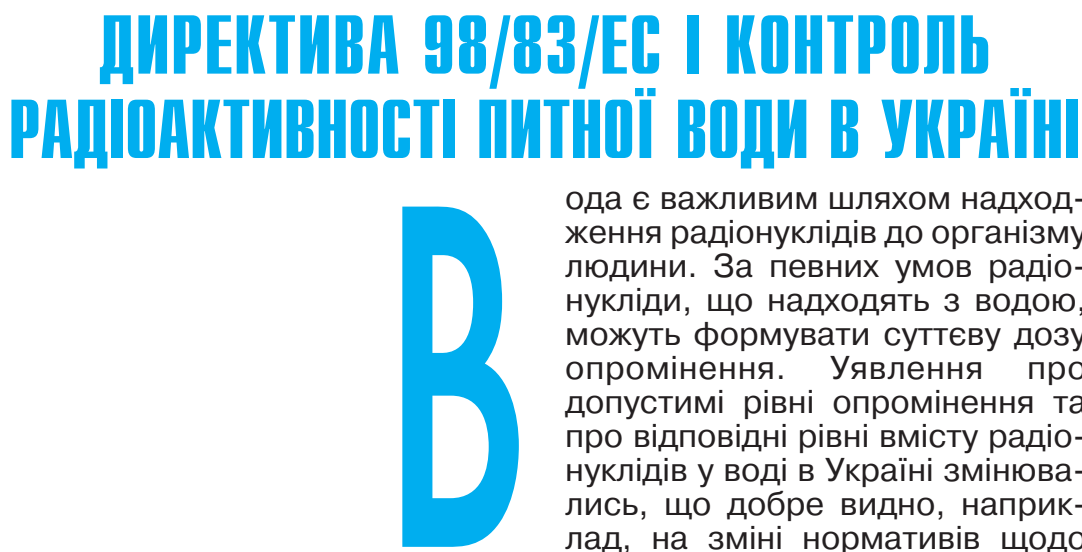

ода є важливим шляхом надходження радіонуклідів до організму людини. За певних умов радіонукліди, що надходять 3 водою, можуть формувати суттєву дозу опромінення. Уявлення про допустимі рівні опромінення та про відповідні рівні вмісту радіонуклідів у воді в Україні змінювались, що добре видно, наприклад, на зміні нормативів щодо вмісту урану у воді [1]. Норми радіаційної безпеки України

БУзИНнИЙ М.Г. (НРБУ-97) розглядають радіо-

ду «Інститут громадського нукліди у воді як джерело опромінення за певних умов, а природні радіонукліди - як потенційне джерело опромінення для НАМН України», м. Київ

УДК 614.777:351.777.6:539.16 широкого загалу населення [2] Радіонукліди антропогенного походження мають обмежене часове та/або просторове поширення, що видно на прикладі пізньої стадії аварії на ЧАЕС, коли їхня дія обмежена. Розширення області нормування опромінення за рахунок води на все населення збільшує кількість необхідних досліджень, зумовлює запровадження оптиміза-

\section{ДИРЕКТИВА 98/83/ЕС И КОНТРОЛЬ РАДИОАКТИВНОСТИ}

\section{ПИТЬЕВОЙ ВОДЫ В УКРАИНЕ}

Бузынный М.Г.

ГУ «Институт общественного здоровья им. А.Н. Марзеева НАМН

Украины», Г. Киев

Цель исследований. Анализ методических подходов к контролю радиоактивности питьевой воды, обоснование действий и рамок действия различных нормативов и методов.

Материалы и методы исследований. При исследовании воды применялись различные радиометрические и спектрометрические методы, которые удовлетворяют правилам достаточной избирательности и чувствительности, что позволяет выполнять ограничение по нормируемой величине радиоактивности и/или дозы. Результаты исследований. Проанализированы методические подходы к контролю радиоактивности питьевой воды в Украине. Разграничены приоритеты применения требований НРБУ-97, ГСанПиН 2.2.4-171-10, Директивы 98/83/ЕС о радиоактивности воды, обоснованы алгоритмы проведения исследований на выполнение требований действующих нормативов и особенности распространения указанных нормативов.

Выводы. Существующие нормативы НРБУ-97, ГСанПиН 2.2.4171-10, касающиеся радиоактивности питьевой воды, включают или дополняют друг друга, а для расширения сферы действия требований Директивы 98/83/ЕС на территории Украины необходимо сначала утвердить соответствующие изменения в ГСанПиН 2.2.4-171-10

Ключевые слова: Директива 98/83/ЕС, естественная радиоактивность воды, тритий, радон, суммарная бета-активность и суммарная альфа-активность, $226 R a, 228 R a$, суммарная активность изотопов урана, $90 \mathrm{Sr},{ }^{137} \mathrm{Cs},{ }^{224} \mathrm{Ra}, 210 \mathrm{~Pb}, 210 \mathrm{Po}$. 